Atıf için / For Citation: H. Arslan, M. Yavuz, "Estimation of surface tension and viscosity of liquid Ag-Cu alloys", Süleyman Demirel Üniversitesi Fen Edebiyat Fakültesi Fen Dergisi, 16(1), 46-65, 2021.

\title{
Estimating of Surface Tension and Viscosity of Liquid Ag-Cu Alloys
}

\author{
Hüseyin ARSLAN ${ }^{* 1}$, Musab YAVUZ ${ }^{2}$ \\ ${ }^{1}$ Kahramanmaras Sütçüimam University, Art \& Science Faculty, Physics Department, 46100, Onikisubat \\ / Kahramanmaras, Turkey \\ ${ }^{2}$ Kahramanmaras Sütçüimam University, Institute for Graduate Studies in Science and Technology, \\ Department of Material Science and Engineering, 46100, \\ Onikisubat / Kahramanmaras, Turkey \\ *corresponding authore-mail: arslan@ksu.edu.tr
}

(Alınış / Received: 04.12.2020, Kabul / Accepted: 13.01.2021, Yayımlanma / Published: 27.05.2021)

\begin{abstract}
The present paper compares the results obtained from the experiments for the binary liquid $\mathrm{Cu}-\mathrm{Ag}$ system at a temperature of $1373 \mathrm{~K}$. All viscosity models available in the existing literature on the viscosity dependence of the viscosity of binary liquid alloys were used. The same process was carried out for surface tension at a temperature of $1423 \mathrm{~K}$ for a dual liquid $\mathrm{Cu}-\mathrm{Ag}$ system. In the literature survey, the Miedema model showed little use in determining the thermophysical properties of this alloy. Using Miedema model, the mixture enthalpy and excess Gibbs free energy in the aforementioned models were calculated. In the present study, a correspondence was found between surface tension and viscosity values. Surface tension and viscosity values were inversely proportional to the temperature, at a fixed silver fraction $\mathrm{x}_{\mathrm{Ag}}$, and directly proportional to copper content at a constant temperature. The obtained results were compared to the data in the existing literature.
\end{abstract}

Key words: Viscosity, Surface tension, Geometric models, Physical models, Butler equation, Miedema's model.

\section{Ag-Cu Sıvı Alaşımlarının Yüzey Gerilimi ve Viskozitesinin Tahmini}

Özet: $\mathrm{Bu}$ çalışmanın amacı, ikili sıvı alaşımların viskozitesinin literatürde bulunan tüm viskozite modelleri kullanılarak, 1373K sıcaklıkta ikili sıvı $\mathrm{Cu}-\mathrm{Ag}$ için yapılan deneylerden elde edilen sonuçları karşılaştırmaktır. Aynı işlem, aynı alaşımın yüzey gerilimi için de $1423 \mathrm{~K}$ sıcaklıkta gerçekleştirilmiştir. Literatür araştırmasında, Miedema modelinin, bu alaşımın termofiziksel özelliklerinin belirlenmesinde çok az kullanıldığı gözlendi. Bunun üzerine, bu çalışmada, Miedema modeli kullanılarak, karışımın entalpisi ve aşırı (fazlalık) Gibbs serbest enerjisi hesaplanmıştır. Bu çalışmada yüzey gerilimi ve viskozite değerleri arasında bir ilişki bulunmuştur. Yüzey gerilimi ve viskozite değerleri, sabit bir gümüş oranında, sıcaklıkla ters orantılı ve sabit bir sıcaklıkta bakır içeriği ile doğru orantılı olarak elde edildi ve sonuçlar literatürdeki mevcut veriler ile karşılaştırıldı.

Anahtar kelimeler: Viskozite, Yüzey gerilimi, Geometrik modeller, Fiziksel modeller, Butler denklemi, Miedema modeli. 


\section{Introduction}

For series of technique / industrial applications, the Ag-Cu system is a very interesting material for joining operations. Processes can be mentioned as soldering, welding and brazing. In particulary, ternary $\mathrm{Sn}-\mathrm{Ag}-\mathrm{Cu}$ alloys (SAC) are used as a replacement material instead of $\mathrm{Sn}-\mathrm{Pb}$ alloys for lead-containing materials.

The Ag-Cu binary alloy is the basic component of many ternary lead-free soldering alloys. This alloy can be used in various fields of technology, while $\mathrm{Ag}$ and $\mathrm{Cu}$ are widely used in the field of electronics for high-temperature applications. One of the concepts related to liquid and solid materials is surface tension concept. Surface tension of binary alloys, viscosity etc. are much easier to understand than ternary alloys. Recently, the investigation of surface tension and viscosity has contributed to the development of new lead-free solder including $\mathrm{Ag}-\mathrm{Cu}$ system. As already known, the measurement of thermodynamic properties is not only difficult, arduous and expensive, but also time-consuming. Therefore, it is challenging to test the thermodynamics parameters of molten metal at a high temperature. It takes a lot of time to test the obtained samples in accordance with theoretical calculations.

The analysis of liquid metals manually is very difficult due to their high temperature and reactivity. $\mathrm{Ag}$ and $\mathrm{Cu}$ elements tend to oxidize at high temperatures. Due to the oxygen adsorption tendency, the surface tensions of the samples vary considerably. Some of the investigations in the existing literature on the surface tension of binary Ag$\mathrm{Cu}$ liquid alloys can be found in references [1-11] thermodynamic properties of materials. Based on the principle of thermodynamics theory, it is obvious that the theoretical calculation of the above-mentioned Eyring theory is a fruitful procedure to investigate [12,2] using several models such as Guggenheim equation $[13,3]$, which is a perfect solution model, improved Guggenheim [12, 2], Butler [14, 15], ideal Butler [16], ideal solution [17, 4] and the geometric model of Kohler [18, 5], Egry models [19, 20] have already been proposed to predict the surface tension of molten alloys. Moreover, it must be noted that various models such as some probabilistic models [21] and regular solutions, sub-regular solutions, self-aggregating model and compound forming models [22] are based on Butler's model.

In addition to surface tension, the thermophysical properties including viscosity and surface tension, of liquid metallic alloys have been modelled thanks to well-known thermodynamics-based methods during the last forty years. Different thermophysical models have been proposed under the light of thermodynamic knowledge to determine the composition and temperature dependence of liquid metallic alloy viscosity. Some of them are given in the following references: Moelwyn-Hughes [23], Iida, Ueda and Morita [24], Kucharski [25], Kozlov, Romanov and Petrov [26], Du Sichen, Boygen and Seetharaman [27], Kaptay [28], Budai et al. [29], Schick et al. [30], Sato [31], Additivity rule (ideal) [32] associated with ideal solution and Gasior model [33] have been recently employed for viscosity estimation in the current literature.

Mixing enthalpy and excess Gibbs free energy expressions in the aforementioned models on binary alloy were calculated by Miedema's model [34], which assumes that liquid binary alloys were composed of Wigner-Seitz cells. It should be known that the 
formation enthalpy in Miedema model for liquid alloys is equal to excess enthalpy, which is not equal to the excess energy. Miedema's model is widely used to calculate the thermodynamic properties of binary alloys such as the mixing enthalpy, excess entropy, excess Gibbs free-energy of a binary. These parameters can be calculated easily in some component activities through various simple physical parameters such as electron negativity, electron density and molar volume.

In the present study, Miedema model was used to calculate the excess entropy, excess Gibbs free-energy of a binary system. Taking the models mentioned above into account, the component activities were measured to evaluate Butler equation for the surface tension and viscosity of $\mathrm{Ag}-\mathrm{Au}$ alloy system. The results were compared with the findings of experimental data and those calculated from the models. It was also demonstrated that there was a correlation between the results of surface tension data and viscosity data calculated using the Egry relation [19, 20]. All these modelling and calculations were made with Matlab2019 program [35].

\section{Theoretical Background of Surface Tension}

Before proceeding, in this section the models shortly will be discussed. Some models are given as follows.

\subsection{Miedema Model}

Some twenty years ago, a model was developed by Miedema in order to offer a simple and widely applicable method for the estimation of the enthalpies of mixing for transition metal alloys. Thanks to this model, enthalpies of mixing for alloys were calculated both in sign and magnitude. The quantities in Eqs. (1)-(6) can be expressed as follows: $\emptyset_{A}^{*}, \emptyset_{B}^{*}$ electronegativity of elements $A$ and $B$ in $e V,\left(n_{w s}^{1 / 3}\right)_{A},\left(n_{w s}^{1 / 3}\right)_{B}$ densities of electrons at Wigner-Seitz cell boundary in $d . u, V_{A}, V_{B}$ molar volume of components $\mathrm{A}$ and $\mathrm{B}$ in $\mathrm{m}^{3}$ and $H_{A B}$ is the formation enthalpy in $\mathrm{kJ} / \mathrm{mol}$,

$$
\begin{gathered}
\mathrm{H}_{\mathrm{AB}}^{0}=\frac{2 \mathrm{p} \mathrm{vA}}{\left[\left(\Delta \mathrm{n}_{\mathrm{ws}}^{1 / 3}\right)_{\mathrm{A}}^{-1}+\left(\Delta \mathrm{n}_{\mathrm{ws}}^{1 / 3}\right)_{\mathrm{B}}^{-1}\right]}\left[9.4^{*}\left(\left(\Delta \mathrm{n}_{\mathrm{ws}}^{1 / 3}\right)^{2}-(\Delta \emptyset)^{2}-\mathrm{a}(\mathrm{R} / \mathrm{p})\right]\right. \\
H_{B A}^{0}=\frac{2 \mathbf{p ~ v B}^{2 / 3}}{\left.\left.\left[\left(\Delta \boldsymbol{n}_{w s}^{1 / 3}\right)_{A}\right)^{-1}+\left(\Delta \mathbf{n}_{w s}^{1 / 3}\right)_{B}\right)^{-1}\right]}\left[9.4^{*}\left(\left(\Delta \mathrm{n}_{w s}^{1 / 3}\right)^{2}-(\Delta \emptyset)^{2}-\mathrm{a}(\mathrm{R} / \mathrm{p})\right]\right. \\
\mathrm{H}_{A \mathrm{~B}}=X_{\mathrm{A}} \mathrm{X}_{\mathrm{B}}\left(\mathrm{X}_{\mathrm{B}}^{s} \mathrm{H}_{\mathrm{AB}}^{0}+\mathrm{X}_{\mathrm{A}}^{s} \mathrm{H}_{\mathrm{BA}}^{0}\right) \\
\mathrm{X}_{\mathrm{A}}^{s}=\frac{\mathrm{X}_{\mathrm{A}} \mathrm{V}_{A}^{2 / 3}}{\mathrm{X}_{\mathrm{A}} \mathrm{V}_{A}^{2 / 3}+\mathrm{X}_{\mathrm{B}} \mathrm{V}_{\mathrm{B}}^{2 / 3}} \\
\mathrm{~V}_{\mathrm{A}}^{\frac{2}{3}}(\text { alloy })=\mathrm{V}_{A}^{\frac{2}{3}}(\text { pure })\left[1+\alpha_{A}\left(\emptyset_{\mathrm{A}}-\emptyset_{\mathrm{B}}\right)\right] \\
\mathrm{V}_{\mathrm{B}}^{\frac{2}{3}}(\text { alloy })=\mathrm{V}_{B}^{\frac{2}{3}}(\text { pure })\left[1+\alpha_{\mathrm{B}}\left(\emptyset_{\mathrm{B}}-\emptyset_{\mathrm{A}}\right)\right]
\end{gathered}
$$

Where $\mathrm{X}_{\mathrm{B}}^{\mathrm{s}}=1-\mathrm{X}_{\mathrm{A}}^{\mathrm{s}}, \Delta \mathrm{n}_{\mathrm{ws}}^{\mathbf{1 / 3}}=\left[\left(\mathrm{n}_{\mathrm{ws}}^{\mathbf{1 / 3}}\right)_{\mathrm{A}}^{-1}-\left(\mathrm{n}_{\mathrm{ws}}^{1 / 3}\right)_{\mathrm{B}}{ }^{-1}, \Delta \emptyset=\emptyset_{\mathrm{A}}^{*}-\emptyset_{\mathrm{B}}^{*}\right.$. 


\subsection{Butler Model}

The surface tension of binary liquid alloys is defined as follows in relation to the Butler model in which the binary alloys are normal solution models:

$$
\sigma=\sigma_{1}+\frac{\mathrm{RT}}{\mathrm{A}_{1}} \ln \left(\frac{\mathrm{X}_{1}^{\mathrm{s}} \gamma_{1}^{\mathrm{s}}}{\mathrm{X}_{1}^{\mathrm{b}} \gamma_{1}^{b}}\right)=\sigma_{2}+\frac{\mathrm{RT}}{\mathrm{A}_{2}} \ln \left(\begin{array}{ll}
\mathrm{X}_{2}^{\mathrm{s}} & \gamma_{2}^{\mathrm{s}} \\
\mathrm{X}_{2}^{\mathrm{b}} \gamma_{2}^{b}
\end{array}\right)
$$

Here, $R, T, \sigma_{i}, A_{i}$ respectively, represent gas constant, $K$ temperature, pure component $\mathrm{i}$ surface tension, and component $\mathrm{i}$, surface area. The area of component $\mathrm{i}$ surface is measured as:

$$
\mathrm{A}_{\mathrm{i}}=1.091 \mathrm{~N}_{a}^{1 / 3}\left(\frac{\mathrm{M}_{i}}{\rho_{i}}\right)^{2 / 3}
$$

Here, $\mathrm{V}_{\mathrm{i}}$ can be defined as $\mathrm{M}_{i} / \rho_{i}$ which denotes each component's molar volume. This expression is determined by using the number $\mathrm{N}_{\mathrm{a}}$ of Avogadro, the atomic mass $\mathrm{M}_{\mathrm{i}}$, and the density data $\rho_{i}$. Here, $X_{j}^{k}$ is an alloy composition with the subscript $j$, and superscript $\mathrm{k}$ denotes the corresponding component $\mathrm{j}$ in the bulk $\mathrm{b}$ and the surface phase s. $\gamma_{i}^{b}\left(T, X_{j}^{b}\right)$ and $\gamma_{i}^{s}\left(T, X_{j}^{s}\right)$ in Eq. (9) represents the activity of component $i$ in the bulk phase and the surface phase, respectively. In the present study, these terms were calculated as the functions of temperature and composition using Miedema model. The activity coefficient of component $\mathrm{i}$ can be obtained from standard thermodynamic relationships in the following form:

$$
\mathrm{G}_{\mathrm{i}}^{E}=\mathrm{RT} \ln \gamma_{i}=\mathrm{G}^{E}+\left(1-\mathrm{X}_{i}\right) \frac{\partial \mathrm{G}^{E}}{\partial \mathrm{X}_{i}}
$$

where $G^{E}$ and $G_{i}^{E}$ represent excess Gibbs free energy and partial molar excess Gibbs free energies. The activities of component $\mathrm{i}$ in $\mathrm{Ag}-\mathrm{Cu}$ alloys are given Section 4. Lee et al. [4] designed a model for $\gamma_{i}^{s}\left(\mathrm{~T}, \mathrm{X}_{\mathrm{j}}^{s}\right)$ in relation $\gamma_{i}^{b}\left(\mathrm{~T}, \mathrm{X}_{\mathrm{j}}^{\mathrm{b}}\right)$ as $\gamma_{i}^{s}\left(\mathrm{~T}, \mathrm{X}_{\mathrm{j}}^{s}\right)=\beta \gamma_{i}^{b}$ $\left(\mathrm{T}, \mathrm{X}_{\mathrm{j}}^{\mathrm{b}}\right)$. Here, $\beta$ parameter denotes the ratio of the coordination number $\mathrm{z}$ in the surface phase, i.e. $\mathrm{z}^{s} / \mathrm{z}^{b}$. In some cases, $\beta$ parameter might be affected by various factors such as the relaxation of the surface structure. In the existing literature, values ranging between $0.5-0.84$ have so far been used [22]. In the surface phase, the number of nearest neighbors surrounding a central atom is 9 . In addition, the coordination number for the bulk atom is 12 . Here, the value of the parameter $\beta$ for liquid metals was taken as 0.83 to calculate surface tensions of the alloy systems [23] in the present study.

\subsection{Ideal Butler Model}

Surface and bulk compositions, $\mathrm{X}_{1}^{\mathrm{s}}$ and $\mathrm{X}_{2}^{\mathrm{s}}$ can be written as $\mathrm{X}_{1}^{\mathrm{s}}=\mathrm{X}_{1}^{B} \exp \left(\sigma-\sigma_{1}\right) A_{1} /$ $R T$ and $\mathrm{X}_{2}^{\mathrm{s}}=\mathrm{X}_{2}^{B} \exp \left(\sigma-\sigma_{2}\right) A_{2} / R T$ from Eq. (7). If these values are added to equation $\mathrm{X}_{1}^{\mathrm{S}}+\mathrm{X}_{2}^{\mathrm{s}}=1$ and exponential terms are expanded as series, the surface tension of the binary alloys can be calculated as:

$$
\sigma=\frac{\mathrm{X}_{1}^{B} \sigma_{1} \mathrm{~A}_{1}+\mathrm{X}_{2}^{B} \sigma_{2} \mathrm{~A}_{2}}{\mathrm{X}_{1}^{B} \mathrm{~A}_{1}+\mathrm{X}_{2}^{B} \mathrm{~A}_{2}}
$$

\subsection{Ideal Solution Model}


In contrary to the viscosity, the surface tension of the alloys in the ideal solution model is not expected to increase, as given by the relation $\sigma=X_{1} \sigma_{1}+X_{2} \sigma_{2}$. Instead of this relation, the following relation can be used:

$$
\sigma=\frac{\sigma_{1} \mathrm{X}_{1}}{\mathrm{X}_{1}+\mathrm{X}_{2} \exp \left(\sigma_{1}-\sigma_{2}\right) A / R T}+\frac{\sigma_{2} \mathrm{X}_{2}}{\mathrm{X}_{2}+\mathrm{X}_{1} \exp \left(\sigma_{2}-\sigma_{1}\right) A / R T}
$$

\subsection{Eyring Theory}

Considering classical statistical thermodynamics formulation by Eyring et al. [11, 36, 37], it is assumed that the melting metal results in freely moving vacancies, and there is a short-range order in the liquid. It is a straightforward manner surface tension expression, which is defined as follows:

$$
\sigma=\frac{V_{S}^{2}}{V^{2}}\left(\frac{k T}{\varphi}\right)\left[0.139 \frac{E_{S}}{R T}-\frac{3}{2} \ln \frac{3}{4}(1+f)\right]
$$

Here, $f$ is equal to a value of 0.287 for all metals. The atomic area is represented by $\varphi$ and it is expressed in terms of Avogadro's number and molar volume as follows:

$$
\varphi=\sqrt{3} / 2\left(\sqrt{2} V_{s} / N_{a}\right)^{2 / 3}
$$

where $\mathrm{N}_{\mathrm{a}}$ is a number for Avogadro. $\mathrm{V}_{\mathrm{s}}=\frac{M}{\rho\left(T_{m}\right)}$ in Eq. (12) refers to the molar quantity of the metal at its melting point $T_{m}$, and $\mathrm{V}$ reflects the molar volume of the metal at temperature $\mathrm{T}(\mathrm{K})$ in such a way that $\rho(\mathrm{T})$ is a temperature function and $\mathrm{M}$ is the atomic weight of the metal under consideration. Moreover, the Boltzmann constant is $\mathrm{k}$ and the universal gas constant is R. $E_{s}$ is described in Eq. (13) as the energy of sublimation for components. Eq. (13) in which the energy of the binary alloys association is as follows:

$$
\mathrm{E}^{\mathrm{s}}=\mathrm{X}_{1}^{2} \mathrm{E}_{1}^{\mathrm{s}}+\mathrm{X}_{2}^{2} \mathrm{E}_{2}^{\mathrm{s}}+2 X_{1} X_{2} \sqrt{E_{1}^{s} \mathrm{E}_{2}^{\mathrm{s}}}
$$

\subsection{Guggenheim Model}

Guggenheim is another model for the surface tension of a perfect binary solution. In a regular solution model of surfaces, an expression concerning surface tension of binary alloys was proposed. This theory yields a relation between $\sigma(\mathrm{X})$ which is between the component surface tensions $\sigma_{1}$ and $\sigma_{2}$ of the form its expression can be written as:

$$
\exp -\left(\frac{\sigma A}{k T}\right)=X_{1} \exp -\left(\frac{\sigma_{1} A_{1}}{k T}\right)+X_{2} \exp -\left(\frac{\sigma_{2} A_{2}}{k T}\right)
$$

where $\sigma$ is the surface tension of the binary alloy, $\sigma_{1}$ and $\sigma_{2}$ denote component surface tensions of the alloy, and $\mathrm{A}$ is the molar surface area of the binary alloy as expressed in the following equation:

$$
A=f^{\prime} N_{a}{ }^{1 / 3} V_{i}{ }^{2 / 3}
$$

$\mathrm{f}^{\prime}$ is the atomic arrangement factor for the liquid surface (1.09 for close packing and 1.12 for body cantered cubic packing) and $\mathrm{A}$ (alloy)=A1=A2. The expressions of density and atomic weight- composition dependences of the alloy can be expressed as: 


$$
V_{i}=M_{i} / \rho_{i}
$$

and

$$
\rho(\text { alloy })=\frac{X_{1} M_{1}+X_{2} M_{2}}{X_{1} V_{1}+X_{2} V_{2}+V^{E}}
$$

Here, $\rho$ and $\rho$ i represent the densities of liquid alloy and pure component $\mathrm{i}$, respectively. Moreover, there is also a relation, i.e. $\rho$ (alloy) $=X_{1} \rho_{1}+X_{2} \rho_{2}$. M and Mi denote atomic weights of the liquid alloy and pure component $i$, respectively. The surface tensions are taken from ref. [9] as $\sigma_{\mathrm{Ag}}=0.841-0.000151(\mathrm{~T}-1235)$ and $\sigma_{\mathrm{Cu}}=1.2$ 0.000212 (T-1357).

\subsection{Improved Guggenheim Model}

A modification of Guggenheim theory can be found when $v_{1}$ and $v_{2}$ are replaced by mole fractions in Eq. (15):

$$
\exp -\left(\frac{\sigma A}{k T}\right)=v_{1} \exp -\left(\frac{\sigma_{1} A_{1}}{k T}\right)+v_{2} \exp -\left(\frac{\sigma_{2} A_{2}}{k T}\right)
$$

where $\left.v_{1}=\frac{\mathrm{V}_{1} \mathrm{X}_{1}}{\mathrm{~V}_{1} \mathrm{X}_{1}+\mathrm{V}_{2} \mathrm{X}_{2}}, v_{2}=1-v_{1}, \quad \mathrm{~A}=\mathrm{V}_{1} v_{1}+\mathrm{V}_{2} v_{2}, A_{i}=V_{i}^{2 / 3}=M_{i} / \rho_{i}\right)^{2 / 3}$

\subsection{Butler Model}

The composition dependence of the surface tensions of mixtures is defined using the following equation, so that the excess surface tension is denoted by $\sigma^{\mathrm{E}}$,

$$
\sigma^{E}=\sigma-\sum \mathrm{x}_{\mathrm{i}} \sigma_{\mathrm{i}}
$$

where $\sigma$ denotes the surface tension of the mixture and $\sigma_{i}$ represents the surface tension of the $\mathrm{i}$ th component of mole fraction $\mathrm{x}_{\mathrm{i}}$.

\section{Theoretical Background of Viscosity}

The viscosity is the resistance or internal friction of a fluid against flow. As the atoms forming liquid slide relatively to each other, they try to prevent the atoms forming the liquid from gaining relative velocity with respect to each other. In this case, a friction occurs between the atoms. When the friction decreases, an increase in the flow ability of the fluids emerges, or it can be said that the viscosities have decreased. As is mentioned above, there is a quite number of thermophysical studies on the variation of viscosity with respect to temperature and composition.

The temperature dependence of the viscosity, $\eta$, can be defined using Arrhenius law:

$$
\eta=\eta_{0} \exp \left(\mathrm{E}_{A} / R T\right)
$$

where $\eta_{0}$ represents the pre-exponential viscosity at a very high temperature. $E_{A}, R$ and $\mathrm{T}$ are the activation energy of viscous flow, the universal gas constant, the temperature, respectively. The expression holds the pure liquid at a high temperature. 
The viscosity values of the metals were found via Arrhenius fits for alloys with different composition in refs. [23, 38].

As in the surface tension expression given in Eq. (21), the viscosity deviation, $\Delta \eta$, can be obtained in the following equation:

$$
\Delta \eta=\eta-\sum x_{i} \eta_{i}
$$

Here, $\eta$ and $\eta i$ are the viscosity of mixture and represent the pure component viscosity, respectively.

The excess surface tension and viscosity variance $\sigma^{\mathrm{E}}$ and $\Delta \eta$ for the binary data are associated with the binary systems in a mixture via a Redlich-Kister form equation:

$$
Z_{i j}=X_{i} X_{i} \sum \mathrm{A}_{i j}^{k}\left(\mathrm{X}_{\mathrm{i}}-\mathrm{X}_{\mathrm{j}}\right)^{\mathrm{k}} \quad \mathrm{k}=0,1,2, \ldots, \mathrm{n}
$$

where $A_{i j}^{k}$ are the coefficients related to the sub-binary i j system. In the present study, the deviations mentioned above were correlated using the Redlich-Kister equation in the following form:

$$
Z_{i j}=X_{2}\left(1-X_{2}\right) \sum A_{i j}^{k}\left(1-2 X_{2}\right)^{\mathrm{k}}, \mathrm{k}=0,1,2, \ldots, \mathrm{n}
$$

\subsection{Kohler Model}

The viscosity deviation concerning Kohler model, which is a geometric model associated with the ternary mixture, is expressed as follows:

$$
\Delta \eta=\left(x_{1}+x_{2}\right)^{2} \Delta \eta_{12}\left(\frac{x_{1}}{x_{1}+x_{2}} ; \frac{x_{2}}{x_{1}+x_{2}}\right)
$$

There are a lot of physical viscosity models. Some of these models are discussed briefly below.

\subsection{Budai-Benko-Kaptay Model}

The viscosity of a multi-component liquid alloy was derived by Budai-Benko-Kaptay and it is expressed as:

$$
\eta=A \cdot \frac{\left(\sum_{i} x_{i} M_{i}\right)^{1 / 2}}{\left(\sum_{i} x_{i} V_{i}+\Delta V^{E}\right)^{2 / 3}} T^{1 / 2} \exp \left[\frac{B}{T}\left(\sum x_{i} T_{m, i}^{*}-\frac{\Delta H}{Q . R}\right)\right], T_{m, i}^{*}=\frac{T}{B} \ln \left[\frac{\eta_{i} V_{i}^{\frac{2}{3}}}{A M_{i}^{\frac{1}{2}} T^{\frac{1}{2}}}\right]
$$

where $M_{i}(\mathrm{~kg} / \mathrm{mol})$ and $V_{i}\left(\mathrm{~m}^{3} / \mathrm{mol}\right)$ represent, respectively, the atomic mass and molar volume of the given metal i. $\Delta \mathrm{H}$ is the integral enthalpy of mixing. This quantity is calculated via Miedema model in the present model. $\mathrm{x}_{\mathrm{i}}$ represents the concentration of component $\mathrm{i}$, and the value of $\mathrm{Q}$ is 25.4 . In the simplest terms, $\Delta \mathrm{V}^{\mathrm{E}}$ denotes the excess molar volume, which is a negligible quantity. $T_{m, i}^{*}$ can be expressed as an effective melting point of the pure component, as given in Eq. (27). A and B in this equation are calculated as $(1.80 \pm 0.39) 10^{-8}\left(\mathrm{~J} / \mathrm{K} \mathrm{mol}^{1 / 3}\right)^{1 / 2}$ and $2.34 \pm 0.20$, respectively.

\subsection{Kozlov-Romanov-Petrov}


Kozlov-Romanov-Petrov equation can be written as in the following equation to calculate the atomic vibration frequencies and describe the viscosity of a liquid:

$$
\ln \eta=\sum_{i=1}^{N} x_{i} \ln \eta_{i}-\frac{\Delta H_{\mathrm{mix}}}{3 R T}
$$

where $\Delta \mathrm{H}_{\text {mix }}$ is the integral enthalpy of mixing, and $\eta_{i}$ and $x_{i}$ represent the viscosity and concentration of the given component $\mathrm{i}$, respectively, $\mathrm{T}$ is the absolute temperature and $\mathrm{R}$ is the universal gas constant.

\subsection{Schick et al. Model}

Recently, to establish the viscosity of $\mathrm{Al}-\mathrm{Cu}$ liquid alloys, a new model differentiated by Schick et al. is given as follows:

$$
\ln \eta=\left(\sum_{i=1}^{N} x_{i} \ln x_{i} \eta_{i, \infty}\right)+\frac{\sum_{i}^{N} x_{i} E_{i}-\Delta H_{\mathrm{mix}}}{R T}
$$

where $E_{i}$ and $\eta_{i, \infty}$ denote the activation energy and pre-exponential factor of viscous flow, respectively.

\subsection{Moelwyn-Hughes Model}

This model can be given for binary alloys as:

$$
\eta=\left(\mathrm{X}_{1} \eta_{1}+\mathrm{X}_{2} \eta_{2}\right)\left(1-\frac{\Delta H_{\mathrm{mix}}}{R T}\right)
$$

where $x_{i}$ represents the mole fraction of component $i$, and $\eta \mathrm{i}$ is the dynamic viscosities of the alloy elements and of pure phase $\mathrm{i}(\mathrm{i}=1,2) . \mathrm{R}=8.315 \mathrm{~J} / \mathrm{mol} \mathrm{K}$ denotes the universal gas constant, $\mathrm{T}$ is the absolute temperature $(\mathrm{K})$, and $\Delta H_{\mathrm{mix}}$ is the mixing enthalpy of the alloy. While the cohesion energy of the alloy is increased, the viscous flow becomes more difficult in this model. This situation is the first to take into accounted by the Moelwyn-Hughes Equation.

\subsection{Iida-Ueda-Morita Model}

The model can be written as:

$$
\begin{gathered}
\eta=\left(\mathrm{X}_{1} \eta_{1}+\mathrm{X}_{2} \eta_{2}\right)\left[2 \sqrt{\left(1+\frac{X_{1} X_{2}\left(\sqrt{M_{1}}-\sqrt{M_{2}}\right)^{2}}{\left(X_{1} \sqrt{M_{1}}+X_{2} \sqrt{M_{2}}\right)^{2}}\right)}-1-\frac{5 X_{1} X_{2}\left(d_{1}-d_{2}\right)^{2}}{X_{1} d_{1}{ }^{2}+X_{2} d_{2}{ }^{2}}-\Delta\right] \\
\text { where } \Delta=0.12 \mathrm{G}^{\mathrm{E}} / \mathrm{R} \mathrm{T} \text { or } \Delta=0.12 \Delta \mathrm{H} / \mathrm{R} \mathrm{T} .
\end{gathered}
$$

In addition to excess thermodynamic terms, the effect of the variations in atomic mass (mi, $\mathrm{kg}$ /atom) and size ( $\mathrm{d}_{\mathrm{i}}$, the double of Pauling's ionic radius of the ions, in $\mathrm{m}$ ) of components such as mixing enthalpy or excess Gibbs free energy is measured in this model. Using the expression $\Delta \mathrm{G}^{\mathrm{E}}=\Delta \mathrm{H}-\mathrm{T} \Delta \mathrm{S}^{\mathrm{E}}$, i.e. the integral excess Gibbs energy, it is possible to measure $\Delta \mathrm{G}^{\mathrm{E}}$ using the mixing heat $(\Delta \mathrm{H})$ and excess mixing entropy $\left(\Delta \mathrm{S}^{\mathrm{E}}\right)$.

\subsection{Kaptay Model}


Given the theoretical relationship between the cohesion energy of the alloy and the activation energy of viscous flow, Kaptay predicted the viscosity in the binary and multicomponent melts using the following formula:

$$
\eta=\frac{h N A}{V} \exp \left[\frac{\sum_{i} x_{i} \Delta E_{\mathrm{i}}-\alpha \Delta H_{\mathrm{mix}}}{R T}\right]
$$

where $\Delta \mathrm{H}_{\text {mix }}$ is the enthalpy of the mixing. $E_{i}$ represents the activation energy of viscous flow, $h$ denotes Planck's constant and $\mathrm{R}=8.315 \mathrm{~J} / \mathrm{mol} \mathrm{K}$ is the universal gas constant.

\subsection{Seetharaman and Sichen Model}

Seetharaman and Sichen proposed the following equation for the viscosity for liquid alloys in terms of the excess Gibbs energy and Gibbs energy activation for viscosity as follows:

$$
\begin{gathered}
\eta=\eta_{0} \exp (\mathrm{E} / R T) \\
\mathrm{E}=\sum_{i} x_{i} \Delta E_{\mathrm{i}}+3 \mathrm{RT} \sum x_{i} x_{j}+\mathrm{RT} \sum x_{i} \ln x_{j}+\mathrm{G}^{\mathrm{E}}
\end{gathered}
$$

E denotes the Gibbs energy of activation for viscosity, which is defined in a multicomponent system as follows:

\subsection{Sato Model}

In 2011, Sato designed a new model for the prediction of alloy viscosity given for binary alloys in the following form:

$$
\eta_{\text {alloy }}=\eta_{\text {alloy }}^{0} \exp \left(\mathrm{E}_{\text {alloy }} / R T\right)
$$

where $\mathrm{E}_{\text {alloy }}=\left(\mathrm{X}_{1} \mathrm{E}_{1}+\mathrm{X}_{2} \mathrm{E}_{2}\right) / R T$ and $\ln \eta_{\text {alloy }}=\mathrm{X}_{1} \ln \eta_{1}^{0}+\mathrm{X}_{2} \ln \eta_{2}^{0}$.

\subsection{Addiativity Rule (Ideal)}

The simplest viscosity model is the additivity rule. The following equation is used for the calculation of the viscosity of the multicomponent alloys from unary data:

$$
\eta=\sum_{i=1}^{N} x_{i} \eta_{i}
$$

where viscosity deviation $\Delta \eta^{\mathrm{E}}$ is assumed as zero in the present study.

\subsection{Egry Model}

In addition to the equations given above, a simple relationship was established by Egry et al. between surface tension and viscosity $[19,20,39]$ in the following form:

$$
\frac{\sigma}{\eta}=\frac{15}{16} \sqrt{\frac{R T}{m N_{a}}}
$$


Here, $\mathrm{R}, \mathrm{T}$ and $\mathrm{m}$ represent universal gas constant, absolute temperature and atomic mass, respectively. Egry's equation can also be used for the estimation of the viscosity liquid alloys such as $\mathrm{Ag}-\mathrm{Cu}$ if the surface tension is known.

\section{Conclusion and Comment}

Different possibilities given above related to surface tension and viscosity were calculated and compared for the $\mathrm{Ag}-\mathrm{Cu}$ system to find the most optimal model in the case of binary alloy systems. Then, the obtained model was applied to $\mathrm{Ag}-\mathrm{Cu}$ system to calculate the surface tensions and viscosities of molten $\mathrm{Ag}-\mathrm{Cu}$ alloy system.

\subsection{Surface tension for $\mathrm{Ag}-\mathrm{Cu}$ system}

The surface tension and viscosity values and the other model parameters for the surface tension and viscosity of pure components at $1423 \mathrm{~K}$ and $1373 \mathrm{~K}$ were taken from the current literature $[9,10]$ for the present study. These parameters for pure liquid metals are given in Table 1. The phase diagram and some thermodynamic properties of $\mathrm{Ag}-\mathrm{Cu}$ alloys were obtained from the existing literature [40]. Some models mentioned above are not analyzed in the present study due to the semi-empirical parameter $\alpha$ in Kucharski's model [25]. The surface tension curves of the $\mathrm{Ag}-\mathrm{Cu}$ alloy system are predicted by the models in Figure 1. The surface tension decreases with Ag concentration at a constant temperature. On the other hand, the appropriate values of Redlich-Kister parameters required for Kohler model on surface tension are determined by fitting experimental data in Brillo et al. [41] in Table 3. A comparison of surface tension of $\mathrm{Ag}-\mathrm{Cu}$ alloys with models Eyring, Guggenheim, Improved Guggenheim, Butler, Ideal Butler, Ideal Solution and Kohler models and experimental data of Brillo et al. for $1423 \mathrm{~K}$ was carried out. Miedema's model was used to calculate the excess Gibbs free energy in Butler model. The Miedema model parameters for Ag and-Cu are given in Table 2. Using Miedema's model, the obtained activity coefficients of Ag and $\mathrm{Cu}$ metals in $\mathrm{Ag}-\mathrm{Cu}$ molten alloy at $1423 \mathrm{~K}$ are given in Table 4. Moreover, using this model, the obtained activities of $\mathrm{Ag}$ and $\mathrm{Cu}$ metals are given in Figure 2. Depending on the properties of the alloy structures, it is quite difficult to adjust the combinations of thermophysical sizes with composition. Only the thermophysical behavior of a few alloy systems may account for the ideal solution model. The liquid $\mathrm{Ag}-\mathrm{Cu}$ alloy exhibits the ideal mixing behavior according to its density [42], which can be associated with the close similarity of the two components. $\mathrm{Ag}$ and $\mathrm{Cu}$ are presented in the group IB of the periodic table. It can be noticed in Table 1 and 2 that the parameters of $n_{w s}^{1 / 3}, \emptyset, V^{2 / 3}$, and surface tension for $\mathrm{Ag}$ and $\mathrm{Cu}$ are very close. These elements are neighbored in the element periodic table. It can thus be concluded that these (elements have similar) properties. Therefore, the absolute values of surface tension factor of these alloys are much smaller, especially in $\mathrm{Ag}-\mathrm{Cu}$ alloy system. This means that $\mathrm{Ag}-\mathrm{Cu}$ alloy is a more ideal molten compared to Al-Cu alloy. On the other hand, the analysis of structural characteristics of liquids leads to different thermodynamic experiences and shows their basic connection, as manifested by the thermophysical properties of temperature and composition dependences such as surface tension, molar viscosity volume, density, etc. Thanks to Eq. (7), we could observe the distribution of the mixture between the surface and the body phase. In binary mixing, Ag content is enriched in the surface phase (Figure 3). In the present study, the root mean square deviations are calculated based on all surface tension models. Eyring model among the all models in the present study offers us a promising model in the study of surface tension at a temperature as high as $1423 \mathrm{~K}$. Therefore, the surface tension values were calculated from Eyring model as a 
function of $\mathrm{Cu}$ content at various temperatures. The obtained graph is shown in Figure 4. Furthermore, the surface tension values were calculated from Eyring model as a function of temperature at various $\mathrm{Cu}$ contents (Figure 5). It is clearly seen in both figures that the surface tension increases along with $\mathrm{Cu}$ concentration at a constant temperature. In Figure 4, the composition dependences of surface tension at a temperature of $1200 \mathrm{~K}, 1300 \mathrm{~K}, 1400 \mathrm{~K}$ and $1500 \mathrm{~K}$ were determined as $\sigma=472.91 \mathrm{X}_{\mathrm{Cu}}$ $+819.03\left(\mathrm{R}^{2}=0.9922\right), \sigma=468.69 \mathrm{X}_{\mathrm{Cu}}+800.55\left(\mathrm{R}^{2}=0.9921\right), \sigma=141.14 \mathrm{X}_{\mathrm{Cu}}{ }^{2}+319.4$ $\mathrm{X}_{\mathrm{Cu}}+801.47\left(\mathrm{R}^{2}=0.9999\right)$ and $\sigma=139.55 \mathrm{X}_{\mathrm{Cu}}{ }^{2}++312.91 \mathrm{X}_{\mathrm{Cu}}+783.58\left(\mathrm{R}^{2}=0.9922\right)$, respectively. Therefore, it can be said that the composition dependences of surface tension were approximately nonlinear with respect to the $\mathrm{Cu}$ content at different temperatures.

Table 1. The model parameters for the surface tension and viscosity at $1423 \mathrm{~K}$ and $1373 \mathrm{~K}$, respectively $[9,10]$.

\begin{tabular}{lcc}
\hline & Components & \\
\hline Parameter & $\mathrm{Ag}$ & $\mathrm{Cu}$ \\
\hline $\mathrm{T}_{\mathrm{m}}(\mathrm{K})$ & 1235 & 1357 \\
Density at $\mathrm{T}_{\mathrm{m}}\left(\mathrm{kg} / \mathrm{m}^{3}\right)$ & 9320 & 8020 \\
Density at $\mathrm{T}\left(\mathrm{kg} / \mathrm{m}^{3}\right)$ & 9185 & 7847 \\
$\mathrm{E}_{\mathrm{s}}(\mathrm{kJ} / \mathrm{mol})$ & 285 & 338 \\
$\mathrm{~V}_{\mathrm{i}}\left(\mathrm{m}^{3} / \mathrm{mol}\right) 10^{-6}$ & 11.72 & 8.09 \\
$\mathrm{~V}_{\mathrm{s}}\left(\mathrm{m}^{3} / \mathrm{mol}\right) 10^{-6}$ & 11.57 & 7.92 \\
$\mathrm{~d}_{\mathrm{i}}\left[\mathrm{m}^{-1} 10^{-10}\right.$ & 2.52 & 1.96 \\
$\eta_{\mathrm{i}}(\mathrm{Pas}) 10^{-3}$ & 3.19 & 3.9 \\
$\sigma_{i}(\mathrm{~N} / \mathrm{m})$ & 0.813 & 1.488 \\
$\phi\left(\mathrm{m}^{2} /\right.$ atom $) \times 10^{-20}$ & 7.82 & 6.1 \\
\hline
\end{tabular}

Table 2. The Miedema model parameters for $\mathrm{Ag}$ and $\mathrm{Cu}$.

\begin{tabular}{lllrcc}
\hline & $\boldsymbol{n}_{\boldsymbol{w} \boldsymbol{s}}^{\mathbf{1 / 3}}$ & $\emptyset$ & $\boldsymbol{V}^{\mathbf{2} / \mathbf{3}}$ & Melting temperature(K) & Transition element \\
\hline $\mathrm{Ag}$ & 1.36 & 4.45 & 4.7 & 1235 & yes \\
$\mathrm{Cu}$ & 1.47 & 4.45 & 3.7 & 1357 & yes \\
\hline
\end{tabular}

Table 3. Redlich-Kister parameters associated with surface tension for $\mathrm{Ag}-\mathrm{Cu}$ in $(\mathrm{mN} / \mathrm{m})$ [43]

\begin{tabular}{lc}
\hline A0 & $-982.68+0.262677 \mathrm{~T}+0.04028137 \mathrm{~T} \ln \mathrm{T}-0.00013536 \mathrm{~T}^{2}$ \\
\hline $\mathrm{A} 1$ & $1625.72-0.693760 \mathrm{~T}-0.09772514 \mathrm{~T} \ln \mathrm{T}+0.00039080 \mathrm{~T}^{2}$ \\
\hline $\mathrm{A} 2$ & $-1142.64-0.084365 \mathrm{~T}+0.14883052 \mathrm{~T} \ln \mathrm{T}-0.00030951 \mathrm{~T}^{2}$ \\
\hline $\mathrm{A} 3$ & $884.43+0.115910 \mathrm{~T}-0.13503940 \mathrm{~T} \ln \mathrm{T}+0.00031221 \mathrm{~T}^{2}$ \\
\hline
\end{tabular}

Table 4. Activity coefficients associated with $\mathrm{Ag}$ and $\mathrm{Cu}$ components at $1423 \mathrm{~K}$.

\begin{tabular}{|c|c|}
\hline \multicolumn{2}{|c|}{$\mathrm{Ag}-\mathrm{Cu}$ for $=1423 \mathrm{~K}$} \\
\hline$\gamma_{\mathrm{Ag}}$ & $\gamma_{\mathrm{Cu}}$ \\
\hline 2.018759 & 1.738493 \\
\hline 1.968442 & 1.596211 \\
\hline 1.936443 & 1.47122 \\
\hline 1.697421 & 1.362322 \\
\hline 1.403028 & 1.268517 \\
\hline 1.181429 & 1.189023 \\
\hline 1.057297 & 1.123305 \\
\hline 1.007474 & 1.071132 \\
\hline 0.998448 & 1.032648 \\
\hline 1.000594 & 1.008496 \\
\hline 1 & 1 \\
\hline
\end{tabular}




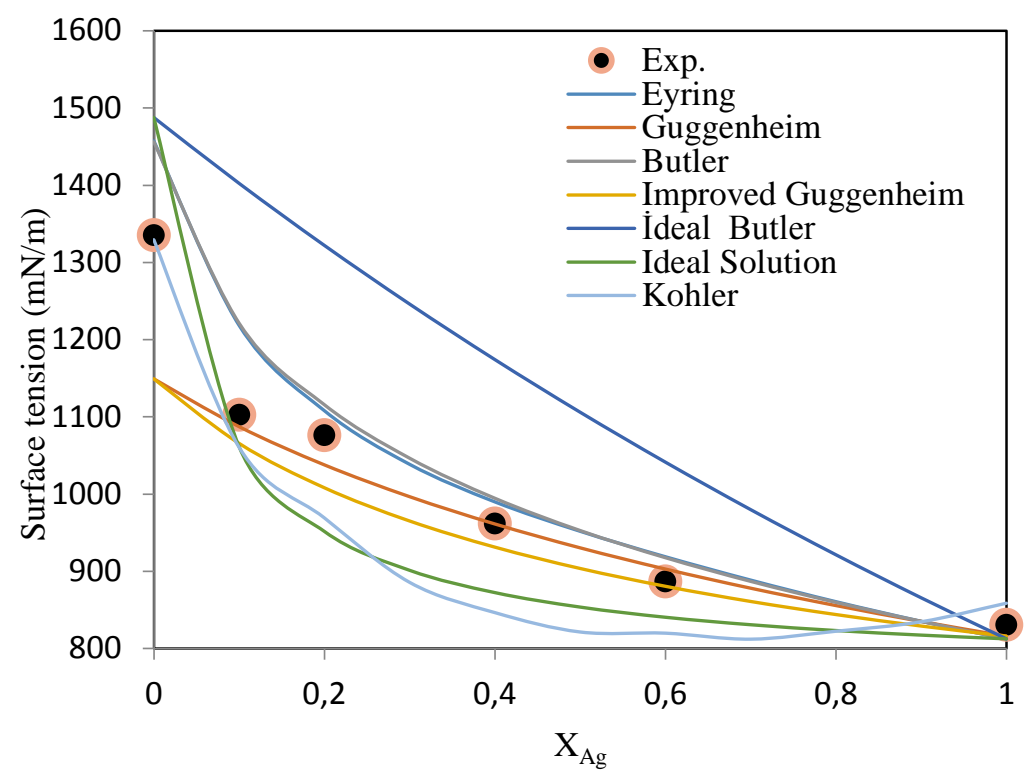

Figure 1. Comparison of surface tension of Ag-Cu alloys with models and experimental results: Eyring, Guggenheim, Improved Guggenheim, Butler, İdeal Butler, Ideal Solution and Kohler models and experimental data of Brillo et al. for $1423 \mathrm{~K}$.

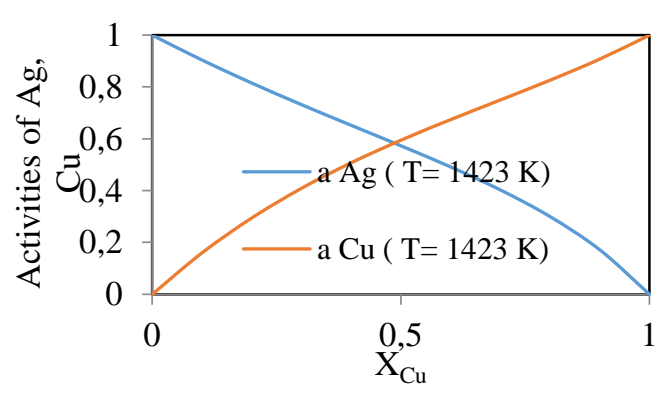

Figure 2. The calculated activities via Miedema's for $\mathrm{Ag}$ and $\mathrm{Cu}$ components at $1423 \mathrm{~K}$.

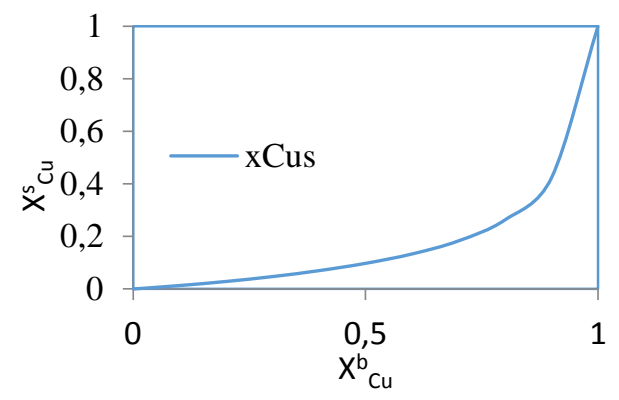

Figure 3. Surface and bulk compositions, $\mathrm{X}_{\mathrm{Cu}}^{S}$ and $\mathrm{X}_{\mathrm{Cu}}^{b}$, of $\mathrm{Cu}$ component which are calculated from Butler model.

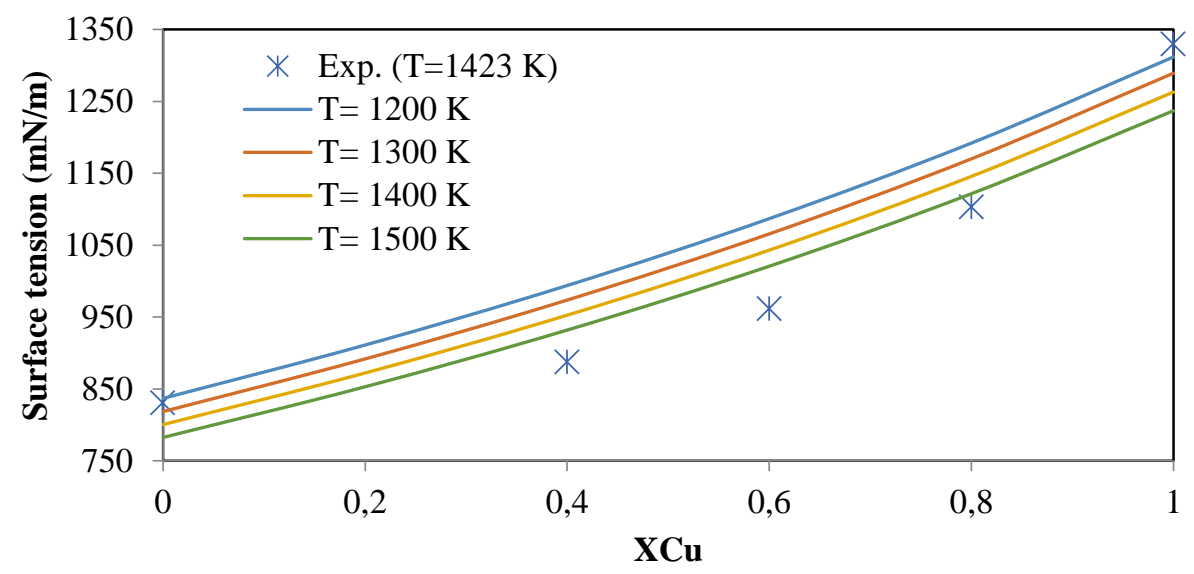

Figure 4. Surface tension values calculated from Eyring model as a function of $\mathrm{Cu}$ content at various temperatures. 


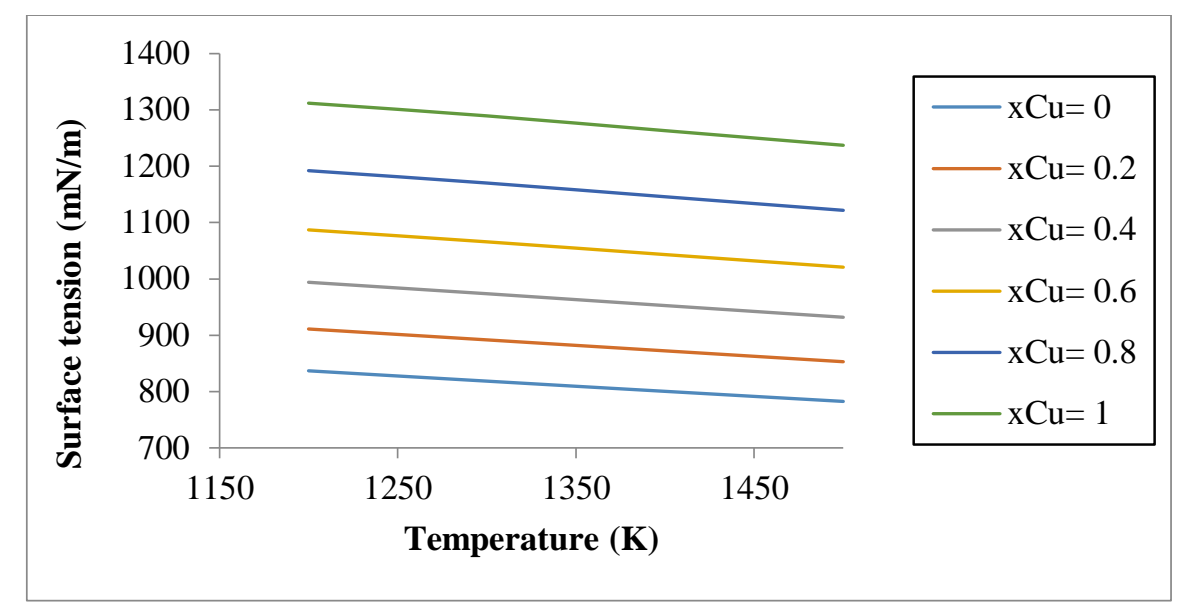

Figure 5. Surface tension values calculated from Eyring model as a function of temperature at various $\mathrm{Cu}$ contents.

These two metals have a similar electronic configuration ([Ar] $3 d^{10} 4 s^{1}$ for $\mathrm{Cu}$ [42] and [Kr] $4 \mathrm{~d}^{10} 5 \mathrm{~s}^{1}$ for $\mathrm{Ag}$ [41]) due to their properties. Figure 4 indicates that the linear variation of surface tension with $\mathrm{Ag}$ and $\mathrm{Cu}$ content is characteristic to an ideal solution. In the present study, one of the most significant results for surface tension was as follows: Since the Eyring model predicts the surface tension better than the other models, surface tension for liquid metals and alloys can be calculated without any further information on the parameters used in the proposed form. Moreover, in order to compare Eyring model with those determined by other authors [1-5, 43, 44], Figure 7 illustrates a function of various $\mathrm{Cu}$ contents of $\mathrm{Ag}_{1-\mathrm{x}}-\mathrm{Cu}_{\mathrm{x}}$ liquid alloys at $1373 \mathrm{~K}$. It demonstrates that the surface tension of the alloy also increases in direct proportion to copper content.

Table 5. The calculated root mean square deviations associated with the all surface tension models.

\begin{tabular}{|c|c|c|c|c|c|c|c|}
\hline Eyring & Guggenheim & Butler & $\begin{array}{c}\text { Improved } \\
\text { Guggenheim }\end{array}$ & $\begin{array}{l}\text { Ideal } \\
\text { Butler }\end{array}$ & $\begin{array}{c}\text { Ideal } \\
\text { Solution }\end{array}$ & Kohler & Ref. \\
\hline 29.5 & 31.9 & 30.06 & 34.1 & 82.1 & 37.6 & 29.6 & [46] \\
\hline
\end{tabular}

The linear variation of surface tension with $\mathrm{Ag}$ and $\mathrm{Cu}$ content is characteristic to ideal solution for the real molten alloy. This is because the interaction of the component in the surface phase, the surface tension, from now on, is not equal to that of the ideal melting alloy. The surface tension factor $\mathrm{F}$ can be assumed and defined to find out the difference of surface tension between ideal mixing and real molten alloy, as its expression is given as $\mathrm{F}=\sigma^{\mathrm{E}} / \sigma_{\text {ideal }}$. Using Miedema's model and Butler equation, surface tension factors of binary $\mathrm{Ag}-\mathrm{Cu}$ and $\mathrm{Al}-\mathrm{Cu}$ alloys were calculated as shown in Figure 6. In this case, the surface tension of real molten of $\mathrm{Al}-\mathrm{Cu}$ alloy is less significant compared to that of the ideal Ag-Cu molten. 


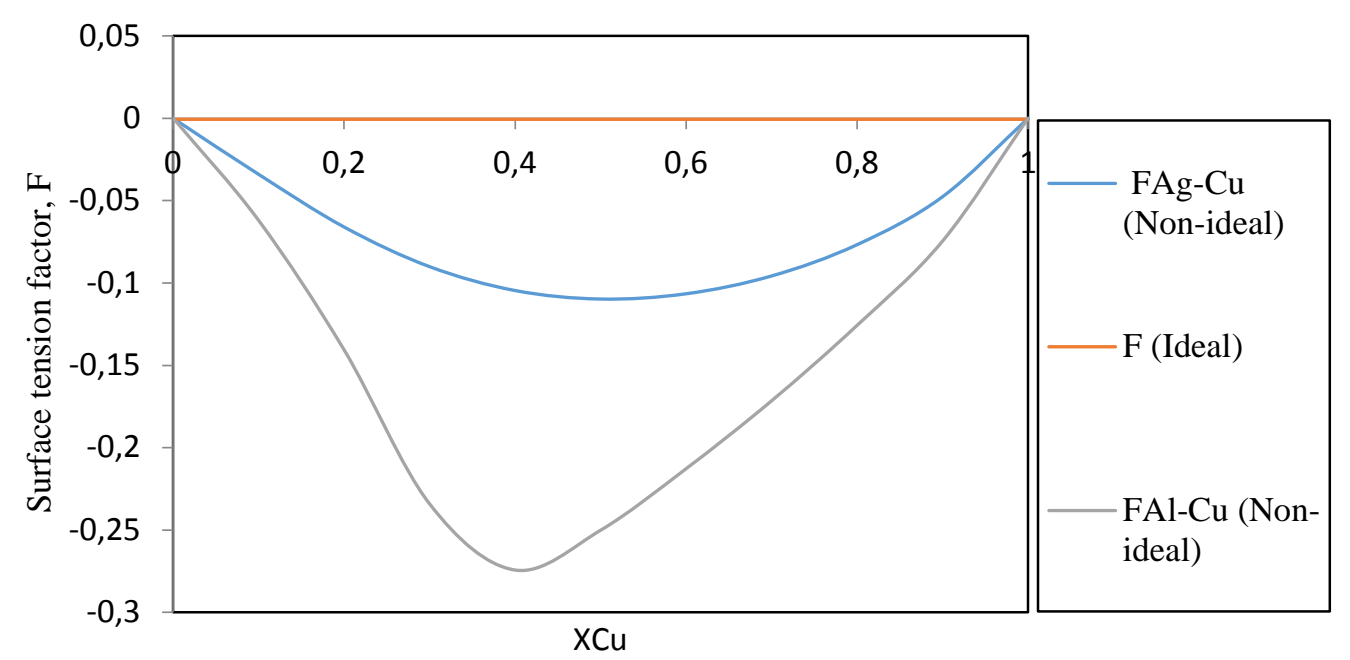

Figure 6. The Surface tension factor, F, calculated Miedema's model for Ag-Cu alloy. The Surface tension factor, F, taken data of Hultgren's model for Al-Cu alloy.

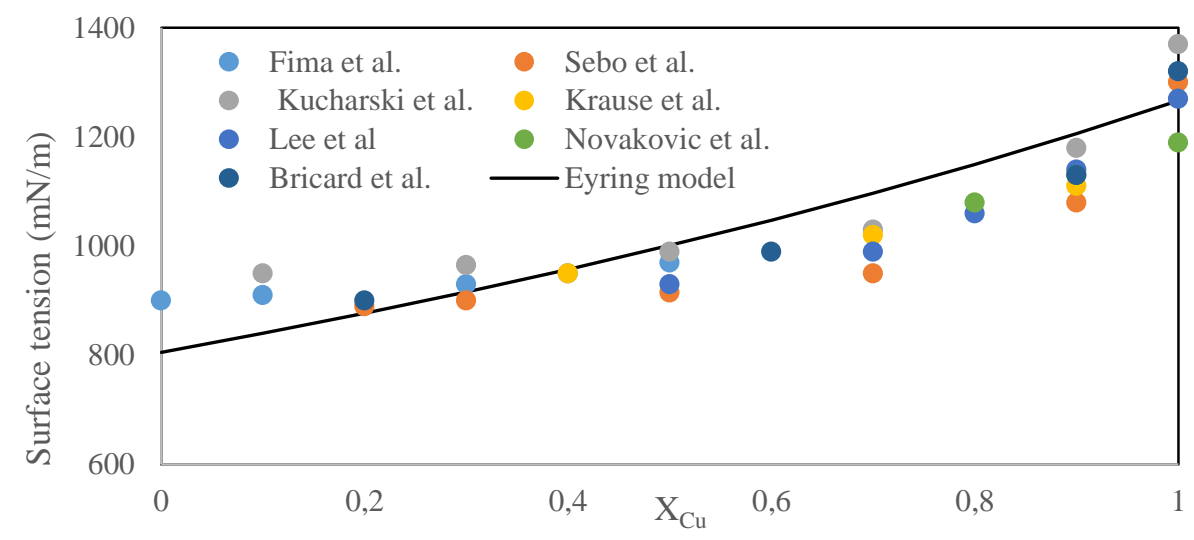

Figure 7. Surface tension values calculated from Eyring model as a function of various $\mathrm{Cu}$ contents at $1373 \mathrm{~K}$.

\subsection{Viscosity for $\mathrm{Ag}-\mathrm{Cu}$ system}

Using the parameters in Table 1 , the viscosity curves of the $\mathrm{Ag}-\mathrm{Cu}$ alloy sytem are predicted by the models in Figure 9 at $1373 \mathrm{~K}$. A comparison of viscosity of $\mathrm{Ag}-\mathrm{Cu}$ alloys with models and experimental results is as follows: Moelwyn-Hughes, Seetharaman and Sichen et al., Schick, Kozlov et al., Kaptay, Iida-Ueda-Morita et al., Hirai, Kohler, Gasior, Sato and Ideal (Additivity rule) and experimental data of Gebhardt et al. for $1373 \mathrm{~K} \mathrm{[45]}$ are shown in Figure 9. In the present study, the root mean square deviations associated with the all viscosity model are calculated. Kozlov et al. offers us a useful model for studying the viscosity at a temperature as high as 1373 K. Similarly, Kohler model offers us an effective model to study the viscosity at the same temperature. The root mean square deviations of the other models were quite close to the above-mentioned models (Table 7). Thus, the viscosity values are calculated from Hirai model as a function of temperature in various $\mathrm{Cu}$ contents. As shown in Figure 9, there is a well agreement between the calculated results using all models in the present study. Generally speaking, another significant finding is that there is a mutual accordance between and experimental and the calculated data. 


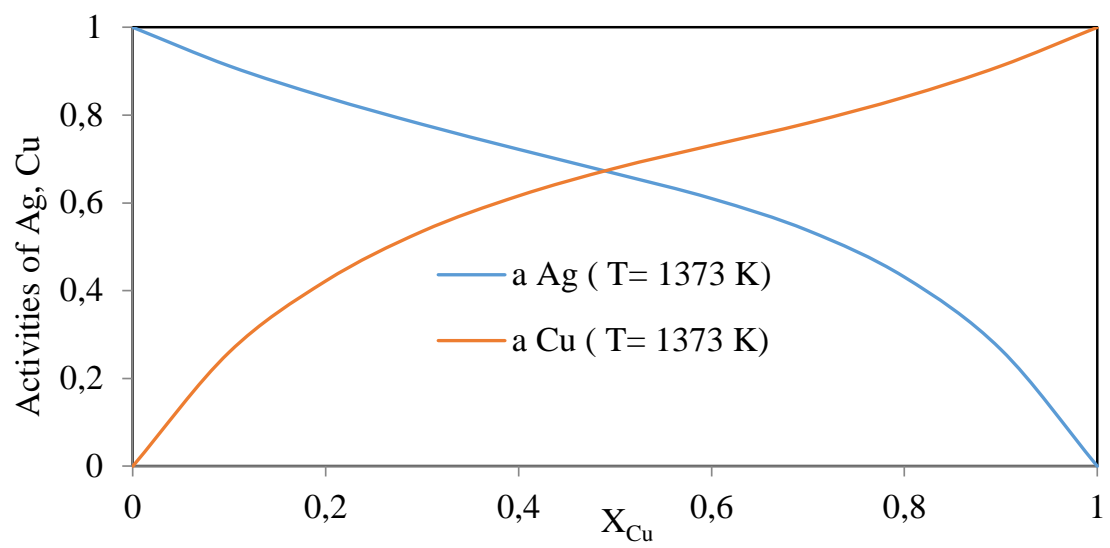

Figure 8. The calculated activities via Miedema's for $\mathrm{Ag}$ and $\mathrm{Cu}$ components at $1373 \mathrm{~K}$.

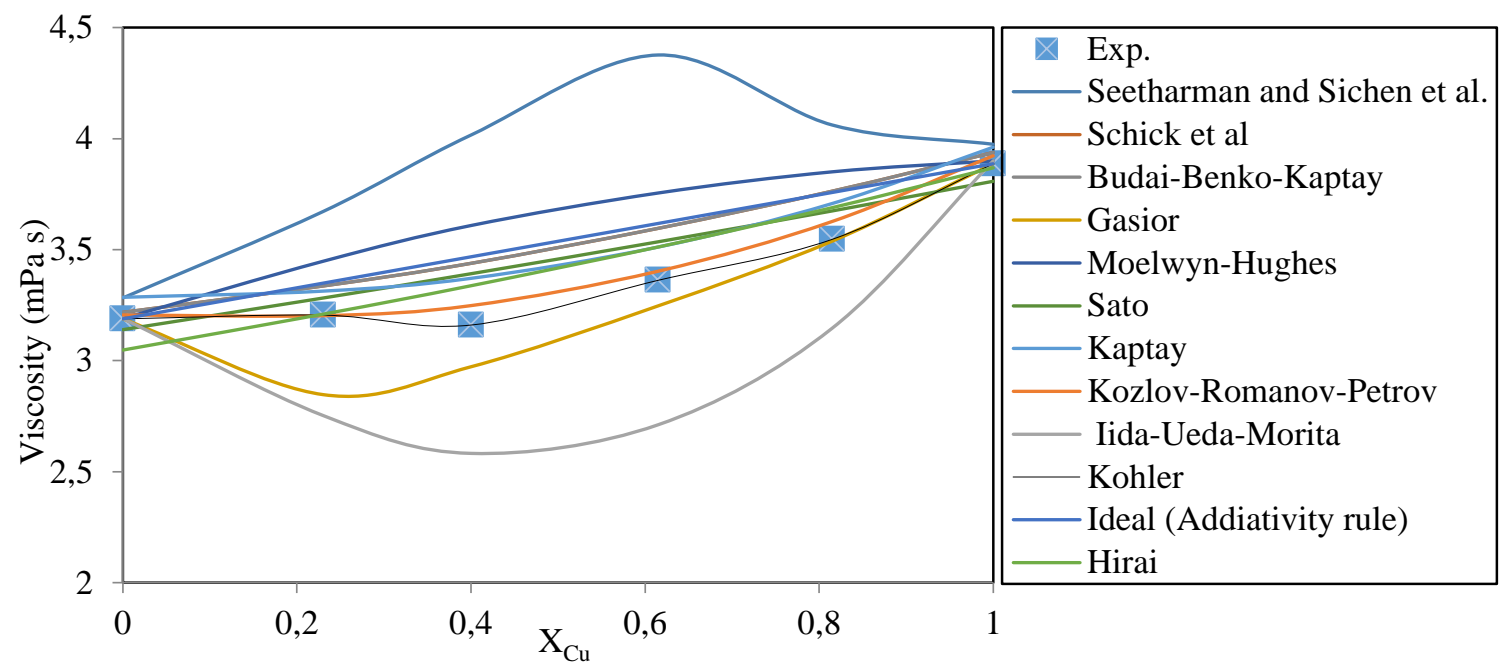

Figure 9. Comparison of viscosity of Ag-Cu alloys with models and experimental results: MoelwynHughes, Seetharaman and Sichen et al, Schick, Kozlov et al., Kaptay, Iida-Ueda-Morita et al., Hirai, Kohler, Gasior, Sato and İdeal (Addiativity rule) and experimental data of Gebhardt et al. for $1373 \mathrm{~K}$ [45].

Table 6. The calculated Redlich-Kister parameters associated with viscosity for $\mathrm{Ag}-\mathrm{Cu}$ in (mN/m).

\begin{tabular}{cccccc} 
& $\mathrm{A}^{0}$ & $\mathrm{~A}^{1}$ & $\mathrm{~A}^{2}$ & $\mathrm{~A}^{3}$ & Ref. \\
\hline$(\mathrm{mPa} \mathrm{s})$ & -1.2148 & -0.5983 & 0.6838 & 3.3333 & This work \\
\hline
\end{tabular}

Table 7. The calculated root mean square deviations associated with the all viscosity models.

\begin{tabular}{|c|c|c|c|c|c|c|c|c|c|c|c|}
\hline Gasior & $\begin{array}{l}\text { Moelwyn- } \\
\text { Hughes }\end{array}$ & Sato & Kaptay & $\begin{array}{l}\text { Kozlov- } \\
\text { Romanov- } \\
\text { Petrov } \\
\end{array}$ & $\begin{array}{l}\text { lida- } \\
\text { Ueda- } \\
\text { Morita } \\
\end{array}$ & Kohler & $\begin{array}{c}\text { İdeal } \\
\text { (Addiativity } \\
\text { rule) }\end{array}$ & Hirai & $\begin{array}{l}\text { Seetharman } \\
\text { and Sichen } \\
\text { et al. }\end{array}$ & $\begin{array}{l}\text { Shick } \\
\text { et al. }\end{array}$ & Benko- \\
\hline 0.0704 & 0.1181 & 0.0559 & 0.0571 & 0.0215 & 0.177 & 0.0006 & 0.0786 & 0.0507 & 0.2500 & 0.0739 & 0.0740 \\
\hline
\end{tabular}

In addition, the surface tension and viscosity of liquid phase were calculated using thermodynamic parameters, such as Redlich-Kister parameters (they are calculated for viscosity in the present study, but are taken those for surface tension from Surdat data [46]) obtained in the present study.

The viscosity values calcul ated from this model as a function of temperature for the sections. Ag- 0.2 at $\% \mathrm{Cu}$ and $\mathrm{Ag}-0.6$ at $\% \mathrm{Cu}$ are plotted in Figure 10. As seen in Figure 10 , the viscosity values increase with increasing $\mathrm{Cu}$ content at a constant temperature. 
Moreover, it should be noted in Figure 10 that the viscosity values declined nonlinearly with increasing temperature in constant $\mathrm{Cu}$ contents.

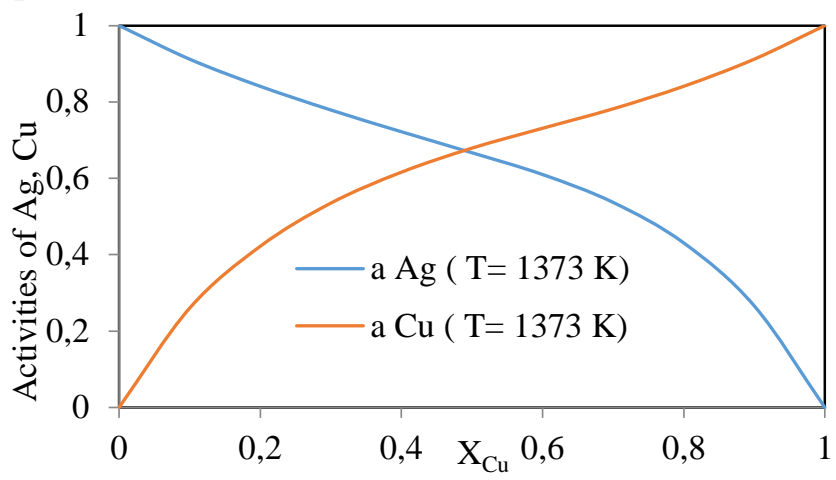

Figure 8. The calculated activities via Miedema's for $\mathrm{Ag}$ and $\mathrm{Cu}$ components at $1373 \mathrm{~K}$.

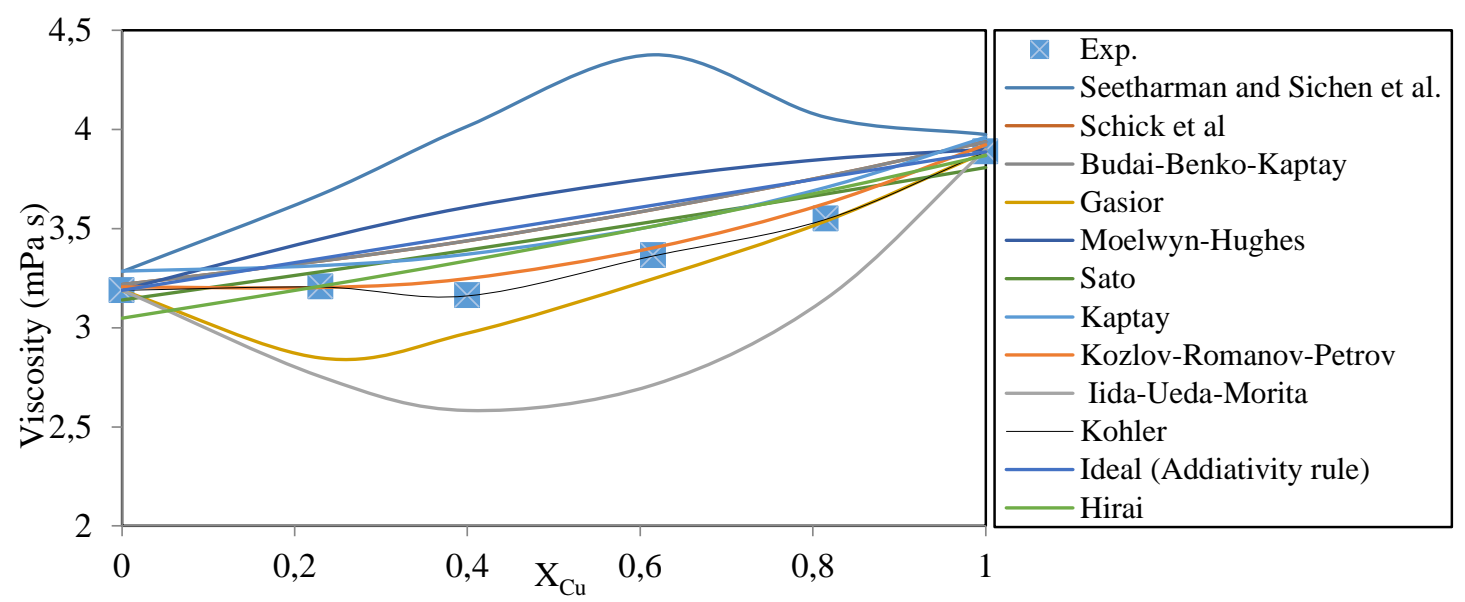

Figure 9. Comparison of viscosity of Ag-Cu alloys with models and experimental results: MoelwynHughes, Seetharaman and Sichen et al, Schick, Kozlov et al., Kaptay, Iida-Ueda-Morita et al., Hirai, Kohler, Gasior, Sato and İdeal (Addiativity rule) and experimental data of Gebhardt et al. for $1373 \mathrm{~K}$ [45].

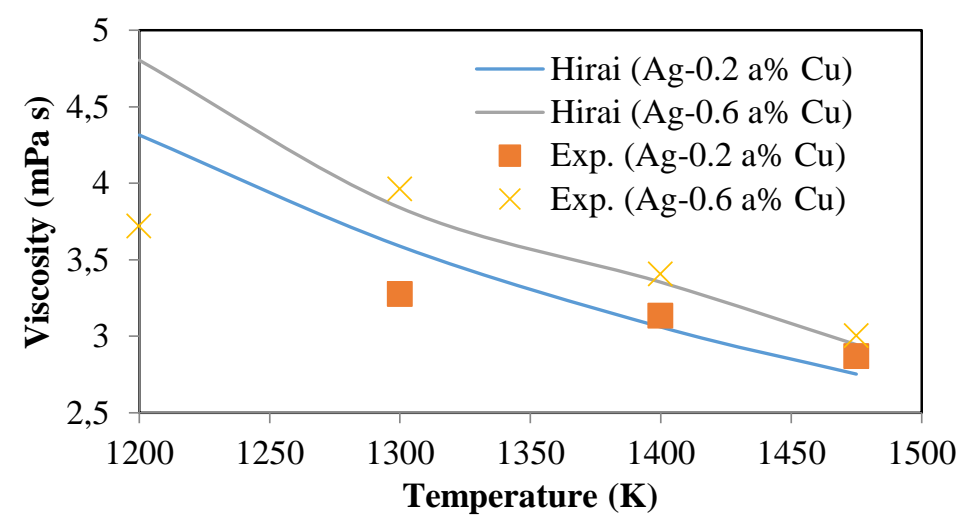

Figure 10. The surface tension values calculated from Hirai model as a function of temperature for the sections $\mathrm{Ag}-0.2$ at \% $\mathrm{Cu}$ and $\mathrm{Ag}-0.6$ at $\% \mathrm{Cu}$.

Using viscosity data given above, the surface tension related with liquid $\mathrm{Ag}-\mathrm{Cu}$ alloy can be derived using Eq. (37) via Hirai model, as shown in Figs. 11 and 12. The average atomic masses for Ag-Cu alloy are calculated between $1.06110^{-25} \mathrm{~kg}$ and $1.80210^{-25}$ among $0<\mathrm{X}_{\mathrm{Cu}}<1$. Both Eyring and Egry models and experimental data show a similar tendency. A rather good agreement can be observed between both models and experimental data for almost all compositions. It can be thus concluded that this method 
offers quite a reasonable relation to obtain surface tension values for $\mathrm{Ag}-\mathrm{Cu}$ alloy and to determine the surface tension of the alloys mentioned above.

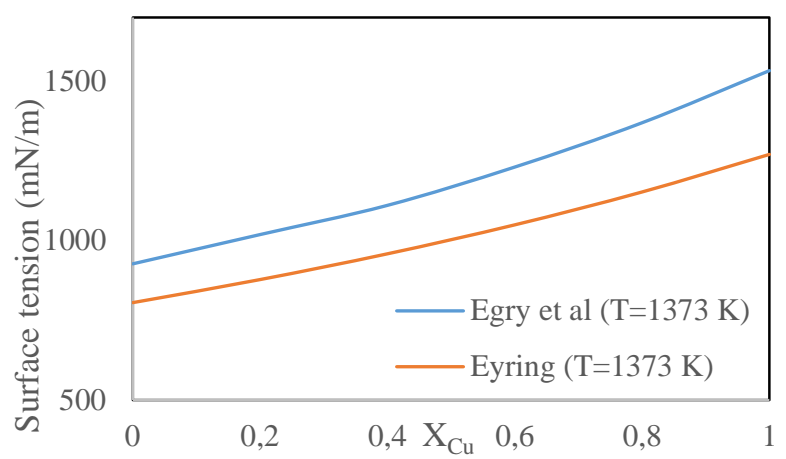

Figure 11. The surface tension values which were calculated using Egry and Eyring models for $\mathrm{Ag}-\mathrm{Cu}$ alloy at $1373 \mathrm{~K}$.

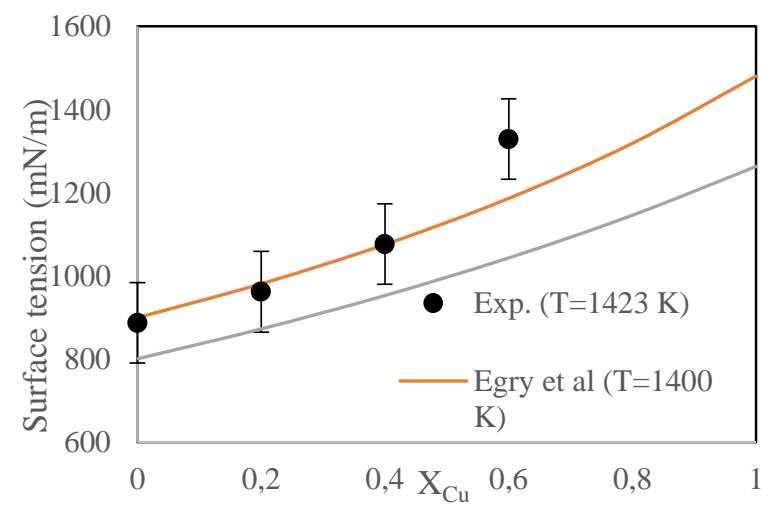

Figure 12. The surface tension values calculated using Egry and Eyring models for Ag-Cu alloy at 1420 $\mathrm{K}$.

The accuracy of the calculated results is related closely to the model used in the mixing enthalpy and excess Gibbs free energy calculation for the surface tension and viscosity as well as the thermophysical models. The surface tensions of $\mathrm{Ag}-\mathrm{Cu}$ are generally in agreement but slightly lower than theoretical results reprted by other researchers [42, 41]. This might have resulted from the fact that Miedema model was used in the mixing enthalpy and excess Gibbs free energy calculation for the Butler's surface tension equation and viscosity relations. Another reason for this case is that the surface tension of the $\mathrm{Ag}$ and $\mathrm{Cu}$ components was used in the measured values in the oxygen medium. It is commonly known for liquid metals that oxygen is the most prominent and ubiquitous surface-active element. It is mentioned in some references [5, 47] that a few ppm of oxygen can reduce surface tension by several percents, and to a sign reversal of the temperature coefficient. Adsorption of oxygen results in a significant metal in the surface tension of the $\mathrm{Ag}$ and $\mathrm{Cu}$ components. Surface tension values from Eyring model as a function of various $\mathrm{Cu}$ contents at $1373 \mathrm{~K}$ are calculated and shown in Figure 7. When compared with surface tension values calculated by other authors, a significant decrease gives rise to a decrease in surface tension of liquid alloy $\mathrm{Ag}-\mathrm{Cu}$. However, concerning to $\mathrm{Ag}$ and $\mathrm{Cu}$, there has been no report on effect of oxygen adsorption as long as the authors in the present study.

In order to verify the calculated results, it would be helpful to conduct further experiments about this system, particularly for the viscosity of the Ag-Cu alloy. 


\section{Conclusions}

According to the calculations performed using molten $\mathrm{Ag}-\mathrm{Cu}$ system, it was observed that the viscosity decreases smoothly with increasing temperature. Moreover, both surface tension and viscosity decrease significantly at high Ag contents.

For this system, Kohler model can be suggested for viscosity calculation and Eyring model for surface tension.

Another reason responsible for the discrepancies among the experiments and surface tension calculations underlies in the that the surface tension of the $\mathrm{Ag}$ and $\mathrm{Cu}$ components were used in the measured values in the oxygen medium. Adsorption of oxygen results in a significant metal in the surface tension of the $\mathrm{Ag}$ and $\mathrm{Cu}$ components. When compared with the surface tension values of other authors, it can be concluded that this significant decrease gives rise to a decreasing surface tension of liquid alloy $\mathrm{Ag}-\mathrm{Cu}$.

The experimental melting temperature measurements are also influenced by the melting of the surface. This can also be another reason responsible for the discrepancies among the experiments and surface tension calculations discussed in the present study.

The accuracy and reliabilities of the models, such as Kohler model, depends on largely the appropriate values of Redlich-Kister parameters for viscosity which can be determined by fitting experimental or other reliable theoretical data. In the present study, Redlich-Kister parameters for viscosity of $\mathrm{Ag}-\mathrm{Cu}$ alloy system were determined by fitting the experimental results. The Redlich-Kister binary interaction parameters for the viscosity of liquid $\mathrm{Ag}-\mathrm{Cu}$ alloy system calculated at $1373 \mathrm{~K}$ in the present study will provide a significant contribution to material science.

\section{Author Statement}

Musab Yavuz: Investigation, Original Draft Writing, Review and Editing.

Hüseyin Arslan: Investigation, Review and Editing, Supervision, Observation, Advice.

\section{Acknowledgment}

The authors are grateful to KSU-BAP (Project No: 2019/6-18 D) for their financial support.

\section{Conflict of Interest}

As the authors of this study, we declare that we do not have any conflict of interest statement.

\section{Ethics Committee Approval and Informed Consent}

As the authors of this study, we declare that we do not have any ethics committee approval and/or informed consent statement.

\section{References}

[1] P. Sebo, B. Gallois, and C.H.P. Lupis, "The surface tension of liquid silver-copper alloys," Metall. Mater. Trans. B, 8(3), 691-693, 1977.

[2] M. Kucharski, P. Fima, P. Skrzyniarz, and W. Przebinda-Stefanowa "Surface tension and density of Cu-Ag, Cu-In and Ag-In alloys,” Arch. Metall.Mater, 51(3), 389-397, 2006.

[3] W. Krause, F. Sauerwald, and M. Michalke "Die Oberflächenspannung geschmolzener Metalle und Legierungen Die Oberflächenspannung von Gold, Zink, Gold- Kupfer- , Silber- Kupfer- und Eisenlegierungen," Z Anorg Allg Chem., 181(1), 353-371, 1929. 
[4] J. Lee, T. Tanaka, Y. Asano, and S. Hara, "Oxygen adsorption behavior on the surface of liquid CuAg alloys," Mater Trans., 45(8), 2719-2722, 2004.

[5] R. Novakovic, E. Ricci, D. Giuranno, and A. Passerone "Surface and transport properties of Ag-Cu liquid alloys," Surf Sci., 576, 175-187, 2005.

[6] B. Gallois and C.H.P. Lupis "Effect of oxygen on the surface tension of liquid copper." Metall. Mater. Trans. B., 12(3), 549-557, 1981.

[7] A. Kasama, T. Iida, and Z.-I. Morita, "Temperature dependence of surface tension of liquid pure metals.” J Jpn I Met., 40(10), 1030-1038, 1976.

[8] S. Ozawa, M. Nishimura, and K. Kuribayashi, "Surface Tension of Molten Silver in Consideration of Oxygen Adsorption Measured by Electromagnetic Levitation," Int. J. Micro. Sci. App., 33(3), 330310, 2016.

[9] F. Aqra and A. Ayyad, "Theoretical calculations of the surface tension of liquid transition metals," Metall. Mater. Trans. B., 42(1), 5-8, 2011.

[10] F. Aqra, A. Ayyad, "Theoretical calculations of the surface tension of Ag $(1-\mathrm{x})-\mathrm{Cu}(\mathrm{x})$ liquid alloys," J. Alloy Compd, 509(19), 5736-5739, 2011.

[11] H. Eyring and M. S. Jhon, Significant liquid structures. 1969.

[12] K. Grjotheim, J. Holm, and B. Lillebuen, "Sufrace tension of liquid binary and ternary chloride mixtures," Acta Chem. Scan., 26(5), 2050-2062, 1972.

[13] E.A. Guggenheim, "Statistical thermodynamics of the surface of a regular solution," Trans. Faraday Soc., 41(0), 150-156, 1945.

[14] J. Butler, "The thermodynamics of the surfaces of solutions," Proceedings of the Royal Society of London Series A, Containing Papers of a Mathematical and Physical Character, 135(827), 348-375, 1932.

[15] C. Mekler and G. Kaptay, "Calculation of surface tension and surface phase transition line in binary Ga-Tl system,” Mater. Sci.Engin A., 495(1), 65-69, 2008.

[16] G. Zeng and B. Friedrich, Editors, "Influencing the Wettability of HSS-Steels by Addition of Alloying Elements to the Zinc Bath." Proceedings of EMC," 2009, pp.1-18

[17] I. Egry, "The surface tension of binary alloys: simple models for complex phenomena," Int $J$ Thermophys., 26(4), 931-939, 2005.

[18] F. Kohler, "Zur Berechnung der thermodynamischen Daten eines ternären Systems aus den zugehörigen binären Systemen," Monatsh. für Chem., 91(4), 738-740, 1960.

[19] I. Egry, G. Lohöfer, and S. Sauerland, "Surface tension and viscosity of liquid metals," J Non-Cryst Solids., 156, 830-832, 1993.

[20] I. Egry, "On the relation between surface tension and viscosity for liquid metals," Scripta Metall. Mater, 28(10), 1273-1276, 1993.

[21] L. Prasad, R. Singh, V. Singh, and G. Singh, "Correlation between bulk and surface properties of Ag Sn liquid alloys,” J. Phys. Chem. B., 102(6), 921-926, 1998.

[22] J. Miyazaki, J. Barker, and G. Pound, “A new Monte Carlo method for calculating surface tension," J. Chem. Phys., 64(8), 3364-3369, 1976.

[23] EA. Moelwyn-Hughes, Physical Chemistry, vol. 83, S. Oxford: Pergamon Press, 1961.

[24] Z. Morita, T. Iida, M. Ueda, "The excess viscosity of liquid binary alloys," -In: Conference on Liquid Metals 1976, Bristol UK., Institute of Physics, Conference Series, 1977, pp. 600-606.

[25] M. Kucharski, “The viscosity of multicomponent systems," Z Metallkd., 77(6), 393-396, 1986.

[26] L. Y. Kozlov, L. Romanov, and N. Petrov, "Izv. vysch. uch. zav.," Chernaya Metallurgiya, 3, 7-11, 1983.

[27] D. Sichen, J. Bygd'En, and S. Seetharaman, "A model for estimation of viscosities of complex metallic and ionic melts," Metall. Mater. Trans. B., 25(4), 519-525, 1994.

[28] T. Kasai, T. Tanaka, and S. Kiriyama, "Polymerization degree of oligomethionine to determine its bioavailability when added to a low-protein diets," Biosci Biotech Bioch., 60(5), 828-834, 1996.

[29] I. Budai, M. Z. Benkő, and G. Kaptay, "Comparison of different theoretical models to experimental data on viscosity of binary liquid alloys," Mater. Sci. Forum, 537, 489-496, 2007.

[30] M. Schick, J. Brillo, I. Egry, and B. Hallstedt, "Viscosity of Al-Cu liquid alloys: measurement and thermodynamic description," J. Mater. Sci., 47(23), 8145-8152, 2012.

[31] Y. Sato, "Representation of the Viscosity of Molten Alloy as a Function of the Composition and Temperature," Jap. J. App. Phys., 50(11S), 11RD01, 2011.

[32] T. Tanaka, M. Matsuda, K. Nakao, Y. Katayama, D. Kaneko, S. Hara, et al. "Measurement of surface tension of liquid Ga-base alloys by a sessile drop method," Z Metallkd., 92(11), 1242-1246, 2001.

[33] W. Gąsior, "Viscosity modeling of binary alloys, Comparative studies," Calphad., 44, 119-128, 2014. 
[34] A. Miedema, R. Boom, and F. De Boer, "On the heat of formation of solid alloys," J. Less Comm. Metals., 41(2), 283-298, 1975.

[35] Matlab (2020) V, February 01.2020, License number: 161051.

[36] T. S. Ree, T. Ree, and H. Eyring "Significant structure theory of transport phenomena," J. Phys. Chem., 68(11), 3262-3267, 1964.

[37] W. C Lu, M. S Jhon, T. Ree, and H. Eyring, "Significant structure theory applied to surface tension," J. Chem. Phys., 46(3), 1075-1081, 1967.

[38] G. Kaptay, "A unified equation for the viscosity of pure liquid metals," Z. Metallkd., 96(1), 24-31, 2005.

[39] N. Zhao, X. Pan, D. Yu, H. Ma, and L. Wang, "Viscosity and surface tension of liquid Sn-Cu leadfree solders," J Electron Mater., 38(6), 828-833, 2009.

[40] R. Hultgren, P. D. Desai, D. T. Hawkins, M. Gleiser, and K. K Kelley, Selected values of the thermodynamic properties of binary alloys, DTIC Document, 1973.

[41] J. Brillo, G. Lauletta, L. Vaianella, E. Arato, D. Giuranno, R. Novakovic, et al. "Surface Tension of Liquid Ag-Cu Binary Alloys," ISIJ International, 54(9), 2115-2119, 2014.

[42] J. Brillo, I. Egry, and I. Ho, "Density and thermal expansion of liquid Ag-Cu and Ag-Au alloys." Int J Thermophys., 27(2), 494-506, 2006.

[43] P. Fima and N. Sobczak, "Thermophysical Properties of Ag and Ag-Cu Liquid Alloys at $1098 \mathrm{~K}$ to 1573 K," Int J Thermophys., 31(6), 1165-1174, 2010.

[44] A. Bricard, N. Eustathopoulos, J-C Joud, P. Desre, "Surface Tension of Liquid Ag-Cu Alloys by the Sessile-Drop Method," Compt Rend. 276 (22), 1613-1616, 1973.

[45] E. Gebhardt and G. Worwag, "Die innere reibung flussigerlegierungen aus silber-kupfer-gold," $Z$ Metallkd., 43(4), 106-108, 1952.

[46] Z. Moser, W. Gasior, A. Debski, and J. Pstrus, "Surdat: Database of physical properties of lead-free solders," J.Min. Metall. B: Metallurgy, 43(2), 125-130, 2007.

[47] B. J. Keene, K. Mills, J. Bryant, and E. Hondros, "Effects of interaction between surface active elements on the surface tension of iron," Canad. Metall. Quar., 21(4), 393-403, 1982. 